\title{
23. Being-in-common and food relief networks in Metro Manila, the Philippines
}

Tessa Maria Guazon

In this chapter, I reflect on mutual aid networks in the Philippines during the COVID-I9 pandemic, focusing on food relief platforms that were mobilised in the early days of Metro Manila's lockdown in 2020. While mutual aid is commonly understood through the Filipino notion of bayanihan (helping each other in times of need), the COVID-I9 pandemic shed light on new structures of aid, most of which were greatly bolstered by social media platforms. I explore new articulations of what is commonly understood as bayanihan, an often-romanticised aspect of Filipino identity that has been routinely deployed by the Philippine national government in its aid rhetoric during national emergencies. Crises result in altered ways of life. These resulting changes can be understood in the context of 'communities of sense', whereby a community 'recognises a contingent and non-essential manner of being together' (Hinderliter et al. 2009, p.2). This 'contingent being together' is often the outcome of events that, as Jacques Rancière (2009, p.3I) has claimed, 'frame a being-in-common', a mode of togetherness or collectivity that is simultaneously palpable and political.

The COVID-I9 pandemic greatly affected food and livelihood security in the Philippines, with daily wage earners the most gravely affected. To elucidate ways of being together, I refer to my experience with women who had served as partners on a research project on neighbourhoods in Metro Manila. Before the pandemic, our women partners relied on meagre earnings from odd jobs on the streets of Escolta and adjoining areas. Lockdown and ensuing curfews made it impossible for them to continue earning their keep. A faulty public health system, the slow roll-out of assistance from the national government, and a crackdown on citizen-led initiatives greatly hampered the provision of

How to cite this book chapter:

Guazon, Tessa Maria. 2022. 'Being-in-common and food relief networks in Metro Manila, the Philippines'. In: Shin, Hyun Bang; Mckenzie, Murray; and Oh, Do Young (eds) COVID-I9 in Southeast Asia: Insights for a post-pandemic world. London:

LSE Press, pp. 257-27I. DOI: https://doi.org/IO.3 I389/lsepress.cov.w

License: CC BY 4.०. 
assistance and aid to the majority of Filipinos. Food relief networks, including community kitchens and community pantries, provided immediate relief to many in need. These initiatives ensured readily available assistance, and, because they were initiated at the grass roots, they were less burdened by bureaucratic processes.

The next paragraphs provide an overview of how the pandemic affected food supplies and aid provision in the Philippines in light of the national government's response to the public health crisis. These contextualise the necessity of citizen-led food relief initiatives. The latter part of the chapter draws heavily from participatory fieldwork for our neighbourhood research project. They reflect on how social ties and relations of togetherness are formed during situations of crisis.

COVID-I 9 cases in the Philippines surged in the early weeks of March 202I, with more than 5,000 active cases recorded daily (Department of Health 202I). A projection from OCTA Research suggested the numbers could rise to I I,, 00 new cases per day, which was an ominous sign for the economy (CNN Philippines 202I). Rising cases of COVID-ı 9 infections posed a threat to people's sense of security, specifically with regard to their livelihoods and the provision of basic needs. In interviews aired on both television and radio in 2020 , daily wage earners said they would rather leave their homes and brave the virus than die of hunger (Talabong and Gavilan 2020). The national government's task force, together with local government officials, swayed back and forth in the precarious dance of halting the rise of COVID-I9 cases through movement restrictions and fully opening the economy to provide jobs.

Filipinos' sense of security was further threatened by the national government's response to the pandemic. The Philippines was placed under a longer lockdown than other countries in the region, rivalling even that of Wuhan province in China, where the first cases of COVID-I9 were thought to have emerged. While the government was slow to close the Philippines' borders to travellers from nations with widespread outbreaks, it was quick to deploy its military and police forces to patrol the streets during lockdown. Philippine president Rodrigo Duterte declared a public health emergency on 8 March 2020, and a lockdown took effect in Metro Manila and the rest of the island of Luzon on I6 March. Metro Manila and cities across the archipelago were placed under varying degrees of quarantine: community quarantine, enhanced community quarantine (ECQ), and modified enhanced community quarantine (MECQ). A prolonged city-wide lockdown would inevitably cripple the economy, as it would hinder workers' ability to commute a long 
distance to work. The so-called 'granular' or zone-specific lockdowns implemented in 202I seemed ineffectual in stemming the rise of active COVID-I 9 cases. ${ }^{\mathrm{I}}$

With Proclamation No. IO2I, Duterte declared the country would be under a year-long state of calamity from I 3 September 2020 until I 2 September 202I (Aurelio 2020). According to the president, extending the state of calamity would 'afford the national government as well as local government units ample latitude to continue utilising appropriate funds, including the quick response fund' in their response to the public health crisis. The president was also granted special powers to reapportion the 2020 national budget through the Bayanihan to Heal as One Act. The proposed 202I budget of 4.5 trillion Philippine pesos was meant to bolster government response to the public health crisis (CNN Philippines 202I).

\section{A lockdown of draconian proportions}

The government's response to the crisis was continuously marred by other equally worrying developments, including the misappropriation of funds by officials of the state-run health insurer Philippine Health Insurance Corporation (PhilHealth) (Luci-Atienza 2020); the non-renewal of the franchise and subsequent closure of the largest media company in the country, ABS-CBN (IFJ 2020); the continuing spate of activist killings and the arrest of citizens protesting the government's feeble response to the pandemic; and restrictions imposed on individuals and local media critical of the government. ${ }^{2}$ Filipinos grappled with the startling figures of rising COVID-I9 cases in the country, the staggering loans the government amassed in 2020 , and the great numbers of poor people who continued to face hunger during the pandemic.

Official statistics from 2018 placed poverty incidence in the Philippines at $\mathrm{I} 6.7 \%$, translating to $\mathrm{I} 7,000,000$ poor Filipinos (PSA 2020 , p.ii). Furthermore, I2.I\% of Filipino families did not have sufficient income to buy minimum basic needs, including both food and non-food needs (PSA 2020, p.ii). The National Capital Region (NCR) was recorded as having the lowest poverty incidence among families, while the Autonomous Region in Muslim Mindanao (ARMM) had the highest poverty incidence. Secretary of Agriculture William Dar assured Filipinos there was adequate food supply until the end of 202I despite restrictions on mobility (Miraflor 202I). The secretary remained overly optimistic, confident in his projection of a $2.5 \%$ growth rate even though the price of goods continued to soar. 
The Inter-Agency Task Force (IATF) on the COVID-I9 pandemic also instituted a government programme focused on a national food policy, Zero Hunger 202I, led by cabinet secretary Karlo Nograles. The Philippines' National Food Policy was launched in October 2020.3 It endorsed a 'whole-of-nation' approach to eradicating hunger. The Department of Agriculture partnered with the IATF in bringing forward the key policies of the National Food Policy programme, including 'Agriculture 4.0', which aimed for a 'smarter and more efficient industry'. The Zero Hunger task force cites among its accomplishments the creation of the Enhanced Partnership Against Hunger and Poverty, the institutionalisation of the Zero Hunger programme guidelines, the airing of the webinar series Kasapatan at Ugnayan ng Mamamayan sa Akmang Pagkain at Nutrisyon (KUMAIN), the Feeding Programs Initiative for the First Ioo० Days of Life, the launch of Pilipinas Kontra Gutom, and the draft of the proposed Philippine Multi-Sectoral Nutrition Project for the World Bank (Department of Education 2020).4 Despite government pronouncements and the recent institutionalisation of the National Food Policy programme, many Filipino families remained impoverished. Food prices continued to rise, with an estimated increase of $6.7 \%$ year-on-year as of February $202 \mathrm{I}$, the highest recorded food inflation since December 2018 (Trading Economics 202I).

The pandemic also brought about an unprecedented loss of livelihoods, with informal workers and daily wage earners suffering greatly. The impact of the city-wide lockdown and the government's slow response to curbing COVID-I9 cases and the provision of aid was strongly felt by millions of poor Filipinos. This situation was greatly reflected in the life situations of our women research partners in the Southeast Asia Neighbourhoods Network (SEANNET) project, who lived on the streets of Escolta, Manila, and whose struggles to make a living were magnified a thousandfold during the pandemic. I turn to their experiences in the following section.

\section{Survival on the streets of Manila}

Together with artists Alma Quinto and Nathalie Dagmang, I worked closely with our women partners on the Manila case study for the SEANNET research project. The Manila share of the project explored the links between art and urban development. We were keen to understand how arts and culture had been enfolded in urban redevelopment programmes and in processes of gentrification. We also wanted to 
Figure 23.1. Escolta street party, revellers congregate in front of the historic First United Building, 2017

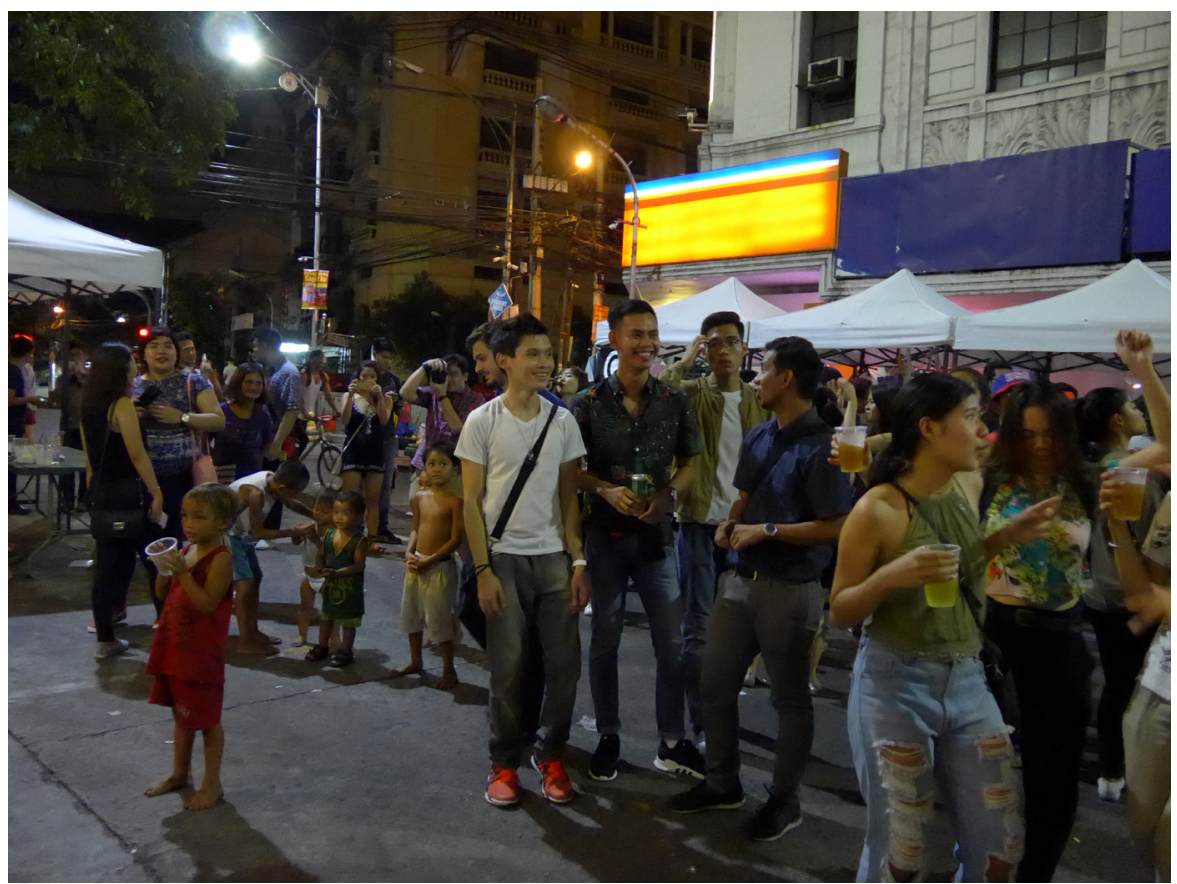

Source: Photograph by the author.

employ the methods and approaches of the visual arts to understand how processes of urban development marginalise and disenfranchise poor and itinerant communities. Often, art collectives, cultural projects, and residency programmes are benignly subsumed into gentrification processes, but there are also approaches that utilise the arts as a means for disadvantaged communities to be heard. We worked with a core group of six women who lived on the streets of Escolta. They were third- and fourth-generation street dwellers and made a living from informal jobs. We were interested to know how informal settlers adapted to changes in the urban fabric. The social ties these women developed with each other were instrumental to their survival on Manila's streets. We wanted to know how neighbourly attitudes helped them survive the hardships of life on the streets.

Escolta used to be a thriving commercial street, linking the River Pasig to both the walled city, Intramuros, and thriving Binondo, Manila's Chinatown. Manila flourished as a port city thanks to the galleon trade in the I7th and I 8th centuries, and even then Escolta housed 
warehouses and bodegas for commercial goods. Manila was heavily bombed under Japanese occupation in World War II, and Escolta fell into ruins. It had a brief revival in the I950s and I960s but became derelict by the I970s, when the city of Manila was overshadowed by rising commercial districts elsewhere in Metro Manila, including Quezon City to the north and Makati to the south. The local government of Manila regarded Escolta as a crucial commercial development corridor. The late I990s thus saw efforts to revitalise the area. There were campaigns to conserve and reuse historic buildings in the area. There were also plans in the early 2000 s for Escolta to adopt a mixeduse development plan, which did not materialise. In the mid-200os, Escolta and other areas in Metro Manila saw a revival through art and cultural events, trendy shops, hip coffee bars and restaurants, bazaars, and street parties. In Escolta, these events or happenings were centred on the historic First United Building, which housed spaces for creatives and start-up businesses, including 98B, an arts initiative that was at the forefront of these projects. These events attracted many visitors to Escolta, mostly young people who lived in other parts of sprawling Metro Manila.

Our women partners made a living by selling candies, instant noodles, and packed-for-retail food items. Two of them ferried passengers across Escolta, Quiapo, and Binondo in their pedicabs. Sol, a busker, also had a thriving makeshift store under a bank's awning, where she and her son had sheltered for years. Brenda and Susan made a living by selling fruits, drinks, and peanuts. These earnings were augmented by their partners' and children's wages. Escolta vendors relied heavily on their suki, or regular customers, for daily earnings, averaging between I 50 and 300 Philippine pesos (around US\$3 or $£_{2}$ to around US\$6 or $£_{4}$ ) on a good day. We witnessed many transitions in their lives in the years we worked with them (i.e. 2017 to 2020). Two moved into rented spaces, which, though still makeshift, were a significant departure from living inside a pedicab or on the streets. One lost a child and found a new partner; another had her son's kidney stones surgically removed; and another's husband recovered from a lingering lung illness. They described their life on the streets as 'pamamangketa', a means of survival and a manner of reciprocity that allowed them to live through everyday hardships. During our often-compelling sessions, they described the difficulties they faced every day, but they would always claim there was a way to live together and 'be in common': to be with another, to feel each other's pain, and to empathise with each other. They cited 
attributes such as 'maabilidad', 'maparaan', and 'madiskarte' (creative and resourceful), as well as 'magaling makisama', 'marunong makisama', 'may malasakit' (to be able to relate well with one another, to feel for each other). These life skills entailed close observation, creativity, interdependence, and shared concern.

In the summer of 2018 , we conducted a cookout and personal history workshop with our women partners. The workshop components, designed by artist Nathalie Dagmang, started with a trip to Divisoria Market to buy ingredients, followed by cooking together and sharing a meal with our women partners and their children. Our women partners were responsible for convening the participants and arranging our transportation to and from the market and the workshop venue. After our shared lunch, we had a personal history session where our women partners connected life events with historical and day-to-day events in Escolta and the adjoining areas of Quiapo and Binondo. It was interesting to note that the women emphatically mentioned how much they missed cooking their meals, which they could not do because they lived in the discreet spots and corners of Escolta Street. The ability to provide meals was a primary concern for our women partners.

Figure 23.2. Shared lunch during our structured cookout at a rented upper floor of a cafeteria in Escolta, May 2018

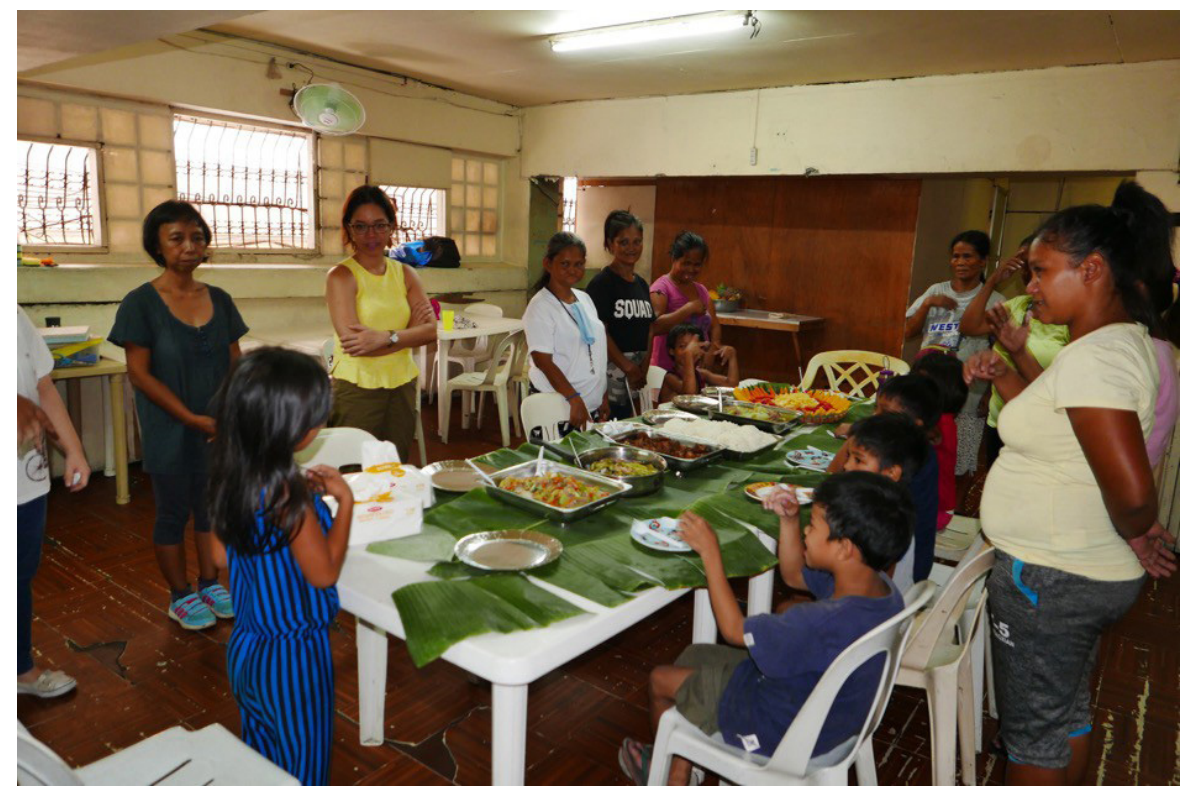

Source: Photograph by Eric Guazon. 
Figure 23.3. Timeline workshop with our women partners, May 2018

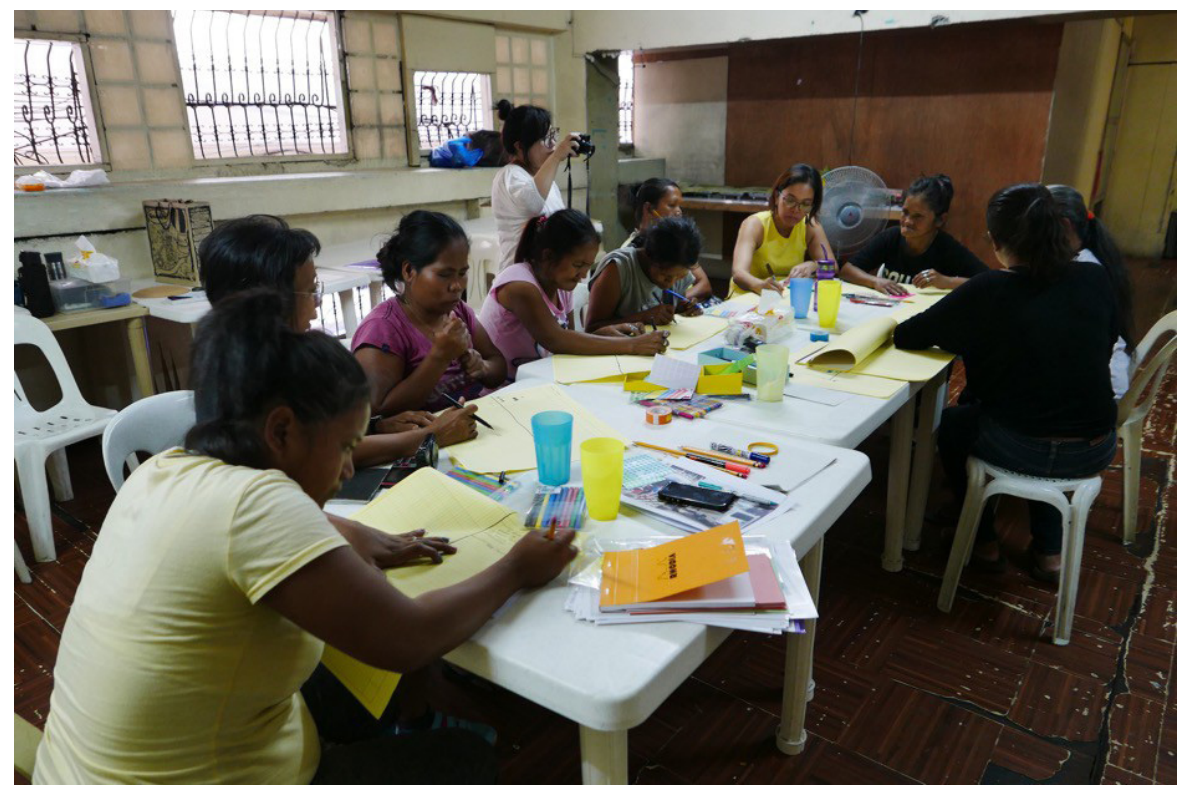

Source: Photograph by Eric Guazon.

\section{Restrictive pandemic policies}

In March 2020, the Philippine National Police made 4I,000 arrests for violations of enhanced community quarantine (ECQ) regulations (Castañeda 2020). The situation was widespread, with a host of informal workers and daily wage earners severely affected by the lockdown and curfews in Metro Manila. Fear and distrust of local police were prevalent among informal settler communities. Similar concerns often came up in discussions with our women partners: recollections of when belongings were carted off during raids; when children were brought by Department of Public Services personnel to holding centres like Boys Town; and how livelihoods were greatly dependent on illegal fees or butaw.

While the National Food Policy had been institutionalised and inaugurated, food provision and food security were matters not easily resolved by the government, especially during lockdown. On I April 2020, residents from Quezon City's Sitio San Roque, one of the Philippines' largest informal settlements, were violently dispersed, with $2 \mathrm{I}$ of the protesters arrested by city police. ${ }^{5}$ They demanded the immediate release of food aid from the local government (CNN Philippines 
2020). Police, on the other hand, claimed residents had violated restrictions on public gatherings by staging a protest without a permit. Six jeepney drivers were likewise jailed on 2 June 2020 in Caloocan (Aspinwall 2020). They rallied for the renewed operation of jeepneys in Metro Manila and the immediate provision of aid by the government. Jeepney drivers lost their wages because of the prolonged suspension of public transportation during the lockdown. Several of them resorted to begging, imploring passers-by and private vehicles for donations (Aspinwall 2020).

Drawing from my own social media network and first-hand knowledge of food provision networks during quarantine in Metro Manila, I observed the development of initiatives like community kitchens (Sitio San Roque's Kusinang Bayan was one such example) and even the private efforts of chefs: Waya Araos-Wijangco of Gourmet Gypsy Art Cafe in Quezon City, for example, transformed her usually bustling kitchen into a food provision hub for frontline workers and drafted guidelines for community kitchens. Other initiatives included those of volunteer groups like Art Relief Mobile Kitchen, which had in the past cooked and provided food for communities affected by disasters. The lockdown gave rise to citizen initiatives propelled by social media, where public calls for contributions, donations, and volunteer work were fielded. They covered a vast array of needs: transportation and lodging for healthcare workers, food relief, direct purchase of produce from farmers, translating health advisories into local languages, and many more.

Artist Nathalie Dagmang reached out to our women partners in March 2020, a day after the lockdown was imposed in Metro Manila. Several of them replied with a sense of panic: the deserted streets meant they would not earn a cent in the coming days, even weeks. Empty streets only meant only one thing: little or to no earnings. Food aid was promised by the national government during the city-wide lockdown. Distribution was left to local barangays (the smallest political administrative units in the Philippines). Our women partners waited for their food packs to arrive, but they had to leave the barangay hall owing to the strict enforcement of curfew during quarantine. Dagmang and I rallied to raise funds for food relief through social media, primarily through a campaign launched by the civil society organisation People for Accountable Governance and Sustainable Action (PAGASA). Food survival packs cost 700 Philippine pesos (US\$ I 5 USD or $£_{\text {II }}$ ) and were meant to tide people over during the first few difficult weeks 
Figure 23.4. Plastic chairs in front of a sari-sari store reserved for the arrival of food packs to be distributed by barangay officials, 2020

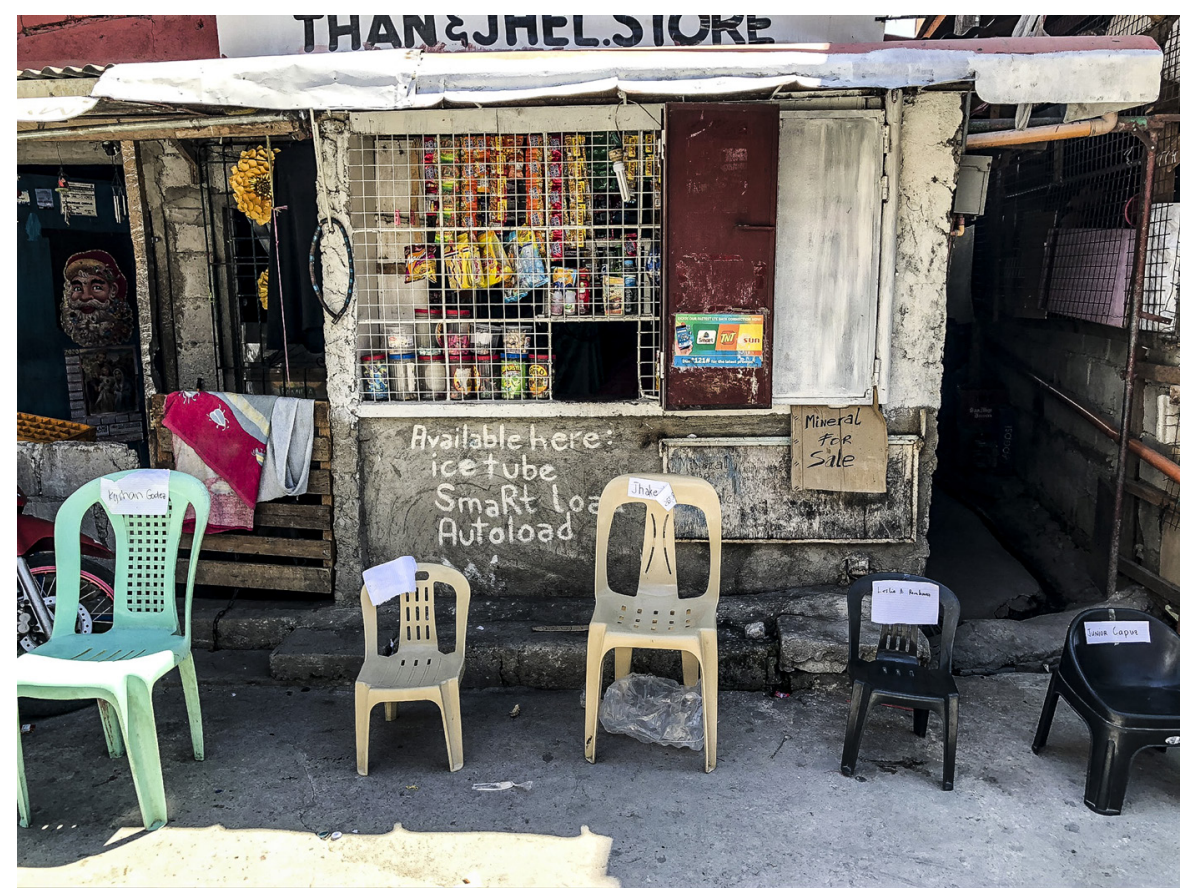

Source: Photograph by Veejay Villafranca.

of lockdown. Reflecting on her experience distributing the food packs, Dagmang (2020) noted numerous challenges to organising the relief drive, including arbitrary rules concerning checkpoints and curfews and, much later, local officials' requirement that the police or military transport and officially release donations and aid to communities outside Metro Manila.

Supplies of rice, vegetables, and canned goods were delivered to Nathalie at no cost and were brought to Escolta through the efforts of another volunteer. Our women partners helped distribute them. Dagmang (2020) noted that these efforts were carried out 'in the spirit of bayanihan', a local expression that refers to a communal spirit and the collective. Environmental historian Greg Bankoff (2020) has cited an even older understanding of bayanihan as arising from a 'rootless struggle with an environment where going it alone is dangerous'. How might we rethink the shared need to provide and sustain others during periods of crisis? How can we recuperate the notion of bayanihan when it has been deployed by the state in its aid efforts and co-opted in its insidious drive to curtail individual freedoms? 


\section{Conclusion: the need for a humane and participatory approach}

The authoritarian nature of the Philippine government's policies only worsened the pandemic situation in the Philippines. The state's overtly militaristic approach resulted in arrests, discrimination, and confusion and did not in any way advance the ready provision of aid to those gravely affected by the pandemic. The proliferation of community pantries and community kitchens across the archipelago showed how mobilisations initiated by citizens were more effective in directly providing assistance.

There exists great potential in mobilising women like our research partners from Escolta to restructure food supply chains in cities. It was often the case that our women partners and their children, more than their partners or husbands, provided for their families. This supports the observation that women have always been 'actively involved in

Figure 23.5 and Figure 23.6. Distribution of food packs in Escolta, Manila
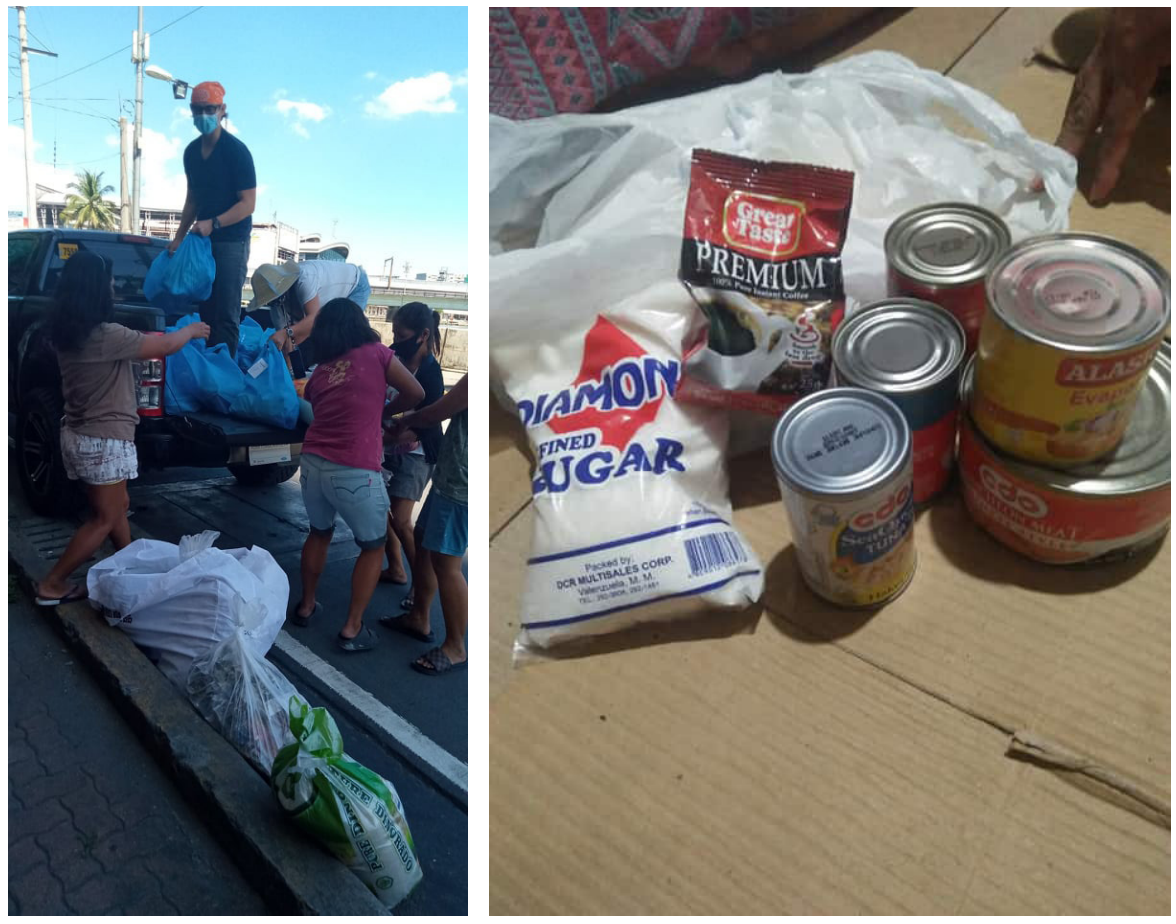

Sources: Photos by Richard Quan and Nathalie Dagmang, respectively.

Note: These were delivered through another intermediary. 
food systems [yet] their contributions [are often] unrecognised and they face many inequities' (Zseleczky et al. 2020).

Our engagement with our women partners from Escolta helped us realise commonplace understandings of reciprocity and cooperation, specifically those shaped by daily struggles deeply rooted in the structural inequities that pervade life in contemporary cities not only in Southeast Asia but around the globe. Perhaps the vital life lessons we overlook and frequently ignore are those we need to learn again from people whose lives are in perpetual crisis. These lessons include the centrality of social ties in weathering crisis situations and thriving after the crisis has passed. In the Philippines, however, citizen-led initiatives were persecuted and received little support from the state. This was evident in the red-tagging of community organisers and the eventual co-optation of their initiatives and projects by local government units - and even by the military (Robertson $202 \mathrm{I}$; Valenzuela 202I). In the context of pervasive repression, these citizen-led movements should instead take the lead.

\section{Notes}

I. Granular lockdowns meant that residents of specific barangays (the smallest political unit in the Philippines) were restricted from leaving their homes, which presented problems for access to food and livelihoods. Some local governments promised the delivery of food packs to affected households, but our experience from 2020 showed that these provisions arrived with great delay. On I9 March 202I, the Philippines recorded the highest count of active COVID-I9 cases, at 7,I03. 'Circuit-breaker lockdowns' were proposed by local government units instead of the more stringent 'general community quarantine' (GCQ).

2. Summary killings and arrests of activists in Manila and other regions continued. Nine activists were gunned down in the Calabarzon region on 7 March 2020, and many individuals, including lawyers and judges, continued to be 'red-tagged', i.e. accused of being affiliated with the Communist Party of the Philippines.

3. According to Nograles, the National Food Policy was geared towards six result areas: the review and rationalisation of existing policies, rules, and regulations related to zero hunger; ensuring available and affordable food; securing nutrition adequacy; securing food accessibility and safety; ensuring sustainable food systems, food resiliency, and stability; and ensuring information, education, awareness, and participation among the people.

4. The Department of Education endorsed the National Food Policy, as it supplemented the department's existing School-Based Feeding Program (SBFP). 
The SBFP provides nutritious meals and milk to learners from kindergarten to Grade 6 whom they describe as 'wasted and severely wasted'. KUMAIN is a consultative platform; it is roughly translated as Practice and Consultation among Citizens on Adequate Food Provision and Nutrition. Pilipinas Kontra Gutom means Philippines Against Hunger.

5. Sitio San Roque used to be home to I 7,000 families, many of whom were migrant workers from the provinces. The government entered a joint venture with Ayala Land Corporation to develop the land they lived on. There were numerous demolitions in the area, with the most violent ones happening in 2010 and 20I4. As of December 20I 8, only 6,000 families were left in Sitio San Roque.

\section{Acknowledgements}

The author acknowledges colleagues from the Southeast Asia Neighbourhoods Network (SEANNET) research project organised by the International Institute of Asian Studies Leiden; the civil society network PAGASA (People for Accountable Governance and Sustainable Action); Richard Quan Lim; and anonymous donors to the food campaign for our women partners from Escolta, Manila. Photojournalist Veejay Villafranca generously lent his images of the city-wide lockdown in Metro Manila. Ideas for this chapter and other outputs for the Manila SEANNET case study were developed alongside research partners Alma Quinto, Nathalie Dagmang, and our research assistants and workshop volunteers over four years of fieldwork. Foremost, these reflections are shaped by valuable insights of our women partners from Escolta: Brenda Aballa, Arlene Garcia, Gilda Descartin, Cecilia Montemayor, Soledad Peña, Susan Soriano, and numerous others who at some point joined our workshop sessions.

Sections of this chapter were initially presented at the 'Bottom-Up Resilience: Civil Society Responses and Marginalised Publics during COVID-ı'' webinar organised by APRU Cities and Landscapes Hub and the Pacific Rim Community Design Network in July 2020.

Written consent was granted by participants to the SEANNET project workshops from the latter part of 2017 to early 2020 , including those from guardians of children who participated in the nutrition and hygiene workshop at Museo Pambata (Children's Museum) in Manila. Consent includes the use of photos and narratives for purely academic purposes by the researchers.

\section{References}

Aspinwall, Nick. (2020). 'Jeepney drivers face charges amid heightened protest crackdown in the Philippines'. The Diplomat, I 2 June. https://perma.cc /HQ2A-RCTT [Last accessed 25 September 2020]. 
Aurelio, Julie M. (2020). 'Duterte extends PH state of calamity'. Philippine Daily Inquirer, I9 September. https://perma.cc/7RRZ-VBYT [Last accessed 24 September 2020].

Bankoff, Greg. (2020). 'In Search of Bayanihan'. Philippine Arts in Venice Biennale. 6 September $2020 \mathrm{https} / / /$ perma.cc/42ME-MQPP [Last accessed 22 September 2020]. (pg 272).

Bulatlat. (202I). "“Bloody Sunday” spells killings, mass arrests in Southern Tagalog'. Bulatlat, 8 March. https://perma.cc/F9WP-7A56 [Last accessed I 8 March 202I].

Castañeda, Jason. (2020). 'Why Duterte won't lift world's longest lockdown'. Asia Times, I5 May. https://perma.cc/Y2F4-3 $\mathrm{HB}_{2}$ [Last accessed 28 September 2020].

CNN Philippines. (2020). '2I protesters demanding food aid arrested in Quezon City', I April. https://perma.cc/B9KT-DNWK [Last accessed 25 September 2020].

CNN Philippines. (202I). 'PH daily COVID-I9 cases could hit I I, o०o by end-March, 20,000 by mid-April - OCTA', I 6 March. https://perma.cc/6X NM-7MLD [Last accessed 6 June 202I].

Dagmang, Nathalie D. (2020). 'Responding to Escolta's street vendors: How do we provide relief and security to the economically vulnerable?' Bulatlat, 2 May. https://perma.cc/5DDY-WMRU [Last accessed 25 September 2020].

Department of Education. (2020). Healthy Learners Make Better Citizens, Says Secretary Briones in IATF Zero Hunger Anniversary, I7 January. https://perma.cc/54PC-6EZC [Last accessed I9 March 202I].

Hinderliter, Beth; Maimon, Vered; Mansoor, Jaleh; and McCormick, Seth (eds) (2009). Communities of Sense: Rethinking Aesthetics and Politics. USA: Duke University Press.

IFJ (International Federation of Journalists). (2020). Independent Journalism and Access to Information Threatened in the Philippines with the Closure of $A B S-C B N$, I June. https://perma.cc/7J72-JMY2 [Last accessed 24 September 2020].

Luci-Atienza, Charissa. (2020). 'PhilHealth corruption at "pandemic level”; House minority bloc urges "complete overhaul”'. Manila Bulletin, I9 August. https://perma.cc/GL7Z-H77E [Last accessed 24 September 2020].

Miraflor, Madelaine B. (202I). 'DA: Food supply enough through 202I'. Manila Bulletin, I2 April. https://perma.cc/TY2V-C8QK [Last accessed 4 May 202I]. 
PSA (Philippine Statistics Authority). (2020). Updated Full Year 2018 Official Poverty Statistics of the Philippines, June 2020. https://perma.cc/8ALS $-\mathrm{YG}_{4} \mathrm{~W}$ [Last accessed I 8 March 202I].

Rancière, Jacques. (2009). 'Contemporary art and the politics of aesthetics', in Beth Hinderliter, Vered Maimon, Jaleh Mansoor and Seth McCormick (eds) Communities of Sense: Rethinking Aesthetics and Politics. USA: Duke University Press, pp. 3 I -50.

Robertson, Phil. (202 I). 'Philippine general should answer for "Red-Tagging". Human Rights Watch, Io February. https://perma.cc/LH 3 Q-6XPG [Last accessed I4 June 202I].

Talabong, Rambo; and Gavilan, Jodesz. (2020). 'Walang wala na: Poor Filipinos fear death from hunger more than coronavirus'. Rappler, 2 April. https://perma.cc/RC9D-HYZ9 [Last accessed 28 September 2020].

Trading Economics. (202I). Philippines Food Inflation. https://perma.cc /WL 3 C-ZFKM [Last accessed I 8 March 202I].

Zseleczky, Laura; Malapit, Hazel; Meinzen-Dick, Ruth; and Quisumbing, Agnes. (2020). 'Transforming food systems for women's empowerment and equity'. IFPRI Blog, I7 April. https://perma.cc/84CZ-ZZER [Last accessed I 8 March 202I]. 